\title{
DETEKSI INFEKSI Human papillomavirus (HPV) 16/18 PADA KARSINOMA SEL SKUAMOSA RONGGA MULUT DENGAN NESTED PCR
}

\author{
Siti Hamidatul 'Aliyah1*), Nelsiani To’bungan2)Jajah Fachiroh3) Nastiti Wijayanti4' \\ ${ }^{1}$ Program Studi Farmasi, STIKES Harapan Ibu Jambi \\ Email: siti.hamidatul.a@mail.ugm.ac.id \\ ${ }^{2}$ Fakultas Teknobiologi, Universitas Atmajaya, Yogyakarta \\ ${ }^{3}$ Bagian Histologi dan Biologi Sel, Fakultas Kedokteran Universitas Gadjah Mada \\ ${ }^{4}$ Fakultas Biologi, Universitas Gadjah Mada
}

Submitted : 16-05-2016, Reviewed: 16-05-2016, Accepted: 17-05-2016

http://dx.doi.org/10.22216/jit.2016.v10i1.394

\begin{abstract}
Head and neck cancer ranks fourth nationally cancer incidence in Indonesia. Oral SCC is one of Head and neck cancer incidence. Oral SCCrelated to several factors, including smoking, alcohol, viral infection human papillomavirus (HPV 16/18) and genetic On the other hand, HPV E6 oncoprotein binds and inactivates TP53, and result in loss of control of the cell cycle.This study aimed to detect HPV 16/18 infection in oral SCC. Detection of HPV serotypes 16 and 18 performed on FFPE DNA isolates oral SCC with the method of nested Polymerase Chain Reaction (PCR). Nested PCR was performed in two stages, namely amplification with L1 primer, followed by specific PCR E6 HPV-16 and HPV-18. A total of $33 \%$ (11/33) FFPE samples showed positive for HPV 18 infection (single-sized DNA bands $415 \mathrm{bp}$ ) and not detected the presence of infection with HPV 16. It can be concluded that the type of FFPE biosampel can be used for studies related to HPV infection. Furthermore, it should be tested on different types biosampel by a larger amount so as to represent the prevalence of oncogenic HPV infection in Indonesia.
\end{abstract}

Keyword: Oral SCC, HPV 16/18, PCR, FFPE

\begin{abstract}
Abstrak
Kanker kepala dan leher menempati urutan kejadian kanker keempat di Indonesia. KSS rongga mulut merupakan salah satu kejadian kepala dan kanker leher. KSS rongga mulut terkait dengan beberapa faktor, termasuk merokok, alkohol, infeksi virus human papillomavirus (HPV 16/18) dan genetic. Di sisi lain, HPV E6 mengikat onkoprotein dan menginaktivasi TP53, dan mengakibatkan hilangnya kontrol dari siklus sel. Penelitian ini bertujuan untuk mendeteksi HPV 16/18 infeksi pada KSS rongga mulut. Deteksi HPV serotipe 16 dan 18 dilakukan pada FFPE DNA isolat SCC lisan dengan metode bersarang Polymerase Chain Reaction (PCR). Nested PCR dilakukan dalam dua tahap, yaitu amplifikasi dengan L1 primer, diikuti dengan PCR spesifik E6 HPV-16 dan HPV-18. Sebanyak 33\% (11/33) sampel FFPE menunjukkan hasil positif untuk HPV 18 infeksi (pita DNA tunggal berukuran 415 bp) dan tidak terdeteksi adanya infeksi HPV 16. Berdasarkan hasil tersebut dapat disimpulkan bahwa metode Nested PCR pada biosampel FFPE dapat digunakan untuk deteksi infeksi HPV pada KSS Rongga Mulut. Penelitian lebih lanjut perlu dilakukan pada jenis biosampel yang berbeda dengan jumlah yang lebih besar sehingga dapat mewakili prevalensi infeksi HPV onkogen di Indonesia.
\end{abstract}

Keyword: KSS Rongga Mulut, HPV 16/18, PCR, FFPE 


\section{PENDAHULUAN}

Jumlah kasus kanker di Asia diperkirakan akan melonjak dari 4,5 juta pada tahun 2002 menjadi 7,1 juta pada tahun 2020 jika tidak dilakukan peningkatan usaha pencegahan maupun penanganan. Berdasarkan data Riset Kesehatan Dasar (Riskesda) tahun 2007 yang diterbitkan oleh Departemen Kesehatan (2008) dinyatakan bahwa tingkat kematian karena kanker di Indonesia adalah sebesar $4 \%$ dari setiap 1000 penduduk. Kasus kematian karena kanker di Indonesia pada tahun 2008 pada laki-laki berkisar pada angka 136.000 jiwa dan perempuan 109.000 jiwa. Di seluruh dunia diperkirakan terdapat 644.000 kasus kanker kepala dan leher, dimana dua pertiga dari kasus tersebut terjadi di negara berkembang.Di negara berkembang, kejadian kanker kepala dan leher lebih banyak terjadi pada laki-laki daripada perempuan dengan rasio 2 banding 1 , sementara di negara maju rasionya mencapai 3 banding 1(Marur, D'Souza, Westra, \& Forastiere, 2010).

Karsinoma Sel Skuamosa Rongga Mulut merupakan salah satu bentuk kanker kepala dan leher yang disebabkan oleh banyak faktor diantaranya karena merokok, mengkonsumsi minuman beralkohol, infeksi virus dan faktor genetis (Blot et al., 1988; Carter et al., 2001; Kabat, Chang, \& Wynder, 1994; McKaig, Baric, \& Olshan, 1998; Sankaranarayanan et al., 1992).

Walaupun merokok dan mengkonsumsi alkohol merupakan faktor utama penyebab terjadinya kanker kepala dan leher, tetapi hal ini tidak terlepas dari adanya perubahan genetis karena adanya mutasi gen. Gen $p 53$ merupakan gen penting yang mengekspresikan protein TP53yang berperan dalam mengontrol siklus sel, diferensiasi sel, memfasilitasi perbaikan DNA jika terjadi kerusakan, modulator untuk respon sel terhadap stress, menekan tumor dengan apoptosis, dan sebagai modulator untuk aktivitas agen anti kanker(Chin, Boyle, Theile, Parsons, \& Coman, 2004; Gasco \& Crook, 2003; Shen, Zheng, Sturgis, Spitz, \& Wei, 2002).

Penelitian lain membuktikan bahwa TP53 (Tumor Protein p53) menjadi tidak fungsional disebabkan karena adanya pengikatan protein oleh Human Papilloma Virus (HPV) (Partridge et al., 2007). Paradigma baru menjelaskan bahwa pasien kanker kepala dan leher pada laki-laki bukan perokok dan tidak mengkonsumsi alkohol dengan rentang usia antara 40 hingga 60 tahun adalah positif HPV. Sebanyak 70\% HPV 16 ditemukan di orofarings pada kanker kepala dan leher. Pada saluran sinonasal, HPV 16 ditemukan $20 \%$ pada Squamosa-Cell Carsinoma (SCC)(Leemans, Braakhuis, \& Brakenhoff, 2011).

Rumah Sakit Kanker Dharmais sebagai Pusat Kanker Nasional sudah memiliki sistem untuk typing HPV baik secara genotyping maupun serotyping pada kejadian kanker serviks, tetapi adanya infeksi HPV pada KSS rongga mulut belum dilakukan penelitian, sehingga penelitian ini akan mempelajari secara molekuler infeksi HPV 16/18 dengan metode PCR

\section{METODE PENELITIAN 1. Isolasi DNA}

DNA genomik diisolasi dari jaringan parafin dengan menggunakan kit Ekstraksi DNA. Semua prosedur isolasi dilakukan dengan mengikuti manual dalam kit tersebut. Sampel DNA dikuantifikasi dengan Nanodrop untuk mengukur banyaknya DNA yang diisolasi. Sampel DNA kemudian disimpan pada suhu $-20^{\circ} \mathrm{C}$ sampai akan dilakukan analisis selanjutnya. 


\section{Typing HPV $16 / 18$ dengan Nested Polymerase Chain Reaction (PCR)}

Semua sampel diamplifikasi untuk typing HPV16/18 menggunakan PCR dengan consencus primer HPV Open Reading Frame (ORF)universal untuk mengamplifikasi L1 region dari HPV tipe6 , 11, 16, 18 dan33. Sekuen dari forward primer yaitu 5'GCMCAGGGWCATAAYAATGG -3' dan reverse primer 5'CGTCCMARRGGAWACTGATC 3'(Manos et al., 1994)dengan program PCR sebagai berikut: Predenaturasi $95^{\circ} \mathrm{C}$ selama 4 menit, Denaturasi $95^{\circ} \mathrm{C}$ selama 30 detik, Annealing $55^{\circ} \mathrm{C}$ selama 30 detik, Polimerasi $72^{\circ} \mathrm{C} 1$ menit 30 detik, post polimerasi $72^{\circ} \mathrm{C} 10$ menit.

Sampel yang telah diamplifikasi denganconsencus primer HPV Open Reading Frame (ORF) di nested PCR menggunakan primer spesifik untuk HPV tipe 16 dan 18. Forward primer untuk HPV 16 yaitu 5'CATTTGTTGGGGTAACCAAC -3' dan reverse primer yaitu 5'TAGGTCTGCAGAAAACTTTC -3' (Manos et al., 1995). Sekuen forward dan reverseprimer spesifik HPV tipe 18 berturut-turut yaitu 5'TGTTTGCTGGCATAATCAAT-3' dan 5'-TAAGTCTAAAGAAAACTTTTC -3' (Manos et al., 1994)dengan komponen reaksidan program PCR pada Tabel 4 dan Tabel 5. Proses penempelan primer HPV 16 dan HPV 18 disajikan pada Gambar 8. Hasil PCR selanjutnya dielektroforesis dengan buffer TBE 1x pH 8 dan Ethidium
Bromide menggunakan gel agarose $2 \%$ pada tegangan 100 volt selama 30 menit. Gel agarose 2\% yang telah dielektroforesis kemudian divisualisasi menggunakan moleculer imager (Gel Doc). Hasil positif menunjukkan fragmen yang diamplifikasi masing-masing berukuran 412 bp dan 415 bp untuk HPV 16 dan HPV 18. Kontrol positif yang digunakan dalam penelitian adalah isolat DNA jaringan segar kanker serviks yang telah teridentifikasi positif HPV 16/18.dengan program PCR sebagai berikut: Predenaturasi $95^{\circ} \mathrm{C}$ selama 4 menit, Denaturasi $95^{\circ} \mathrm{C}$ selama 30 detik, Annealing $56,4{ }^{\circ} \mathrm{C}$ selama 30 detik, Polimerasi $72^{\circ} \mathrm{C} 1$ menit 30 detik, post polimerasi $72^{\circ} \mathrm{C} 10$ menit.

\section{HASIL DAN PEMBAHASAN}

\section{A. Pengumpulan Sampel dan Isolasi DNA}

Sampel penelitian berasal dari 33 pasien yang berdasarkan hasil pemeriksaan histopatologinya menunjukkanKSS Rongga Mulutyang tedaftar di Rumah Sakit Pusat Kanker Nasional Dharmais selama tahun 2008 hingga 2013 (Tabel 5). Semua pasien telah menyetujui keterlibatan dalam penelitian melalui informed concern. Subyek penelitian ini terdiri atas 18laki-laki, dan 15perempuan, dengan rentang umur 19-75tahun. Sampel terdiri dari 33 sampel jaringan FFPE dari pasien kanker kepala dan leher. Detail keterangan sampel dapat dilihat pada Tabel 1 di bawah. 
Tabel 1. Data Klinis Pasien dan Hasil genotyping HPV 16 dan HPV 18 pada sampel FFPE

\begin{tabular}{|c|c|c|c|c|c|}
\hline No & $\begin{array}{l}\text { Kode } \\
\text { Sampel }\end{array}$ & $\mathrm{L} / \mathrm{P}$ & Usia & Marital Status & Status HPV \\
\hline 1 & L1 & $\mathrm{L}$ & 60 & Menikah & Negatif \\
\hline 2 & L2 & $\mathrm{L}$ & 37 & Menikah & Negatif \\
\hline 3 & L3 & $\mathrm{L}$ & 37 & Menikah & HPV 18 \\
\hline 4 & L4 & $\mathrm{P}$ & 37 & Menikah & Negatif \\
\hline 5 & L5 & $\mathrm{P}$ & 49 & Menikah & Negatif \\
\hline 6 & L6 & $\mathrm{L}$ & 27 & Belum & Negatif \\
\hline 7 & L7 & $\mathrm{P}$ & 45 & Menikah & Negatif \\
\hline 8 & L8 & $\mathrm{L}$ & 49 & Menikah & Negatif \\
\hline 9 & L9 & $\mathrm{L}$ & 52 & Menikah & Negatif \\
\hline 10 & L10 & $\mathrm{P}$ & 50 & Menikah & Negatif \\
\hline 11 & L11 & $\mathrm{L}$ & 29 & Menikah & Negatif \\
\hline 12 & L12 & $\mathrm{P}$ & 43 & Menikah & Negatif \\
\hline 13 & L13 & $\mathrm{L}$ & 34 & Menikah & Negatif \\
\hline 14 & L14 & $\mathrm{P}$ & 46 & Menikah & Negatif \\
\hline 15 & L15 & $\mathrm{P}$ & 26 & Belum & Negatif \\
\hline 16 & L16 & $\mathrm{P}$ & 41 & Menikah & Negatif \\
\hline 17 & L17 & $\mathrm{L}$ & 75 & Menikah & Negatif \\
\hline 18 & L18 & $\mathrm{L}$ & 26 & Menikah & Negatif \\
\hline 19 & L19 & $\mathrm{L}$ & 25 & Menikah & Negatif \\
\hline 20 & L20 & $P$ & 43 & Menikah & Negatif \\
\hline 21 & L21 & $\mathrm{P}$ & 54 & Menikah & Negatif \\
\hline 22 & L22 & $\mathrm{L}$ & 19 & Belum & Negatif \\
\hline 23 & $\mathrm{~L} 23$ & $\mathrm{P}$ & 55 & Menikah & Negatif \\
\hline 24 & L24 & $\mathrm{L}$ & 26 & Menikah & HPV 18 \\
\hline 25 & $\mathrm{~L} 25$ & $\mathrm{P}$ & 68 & Menikah & HPV 18 \\
\hline 26 & L26 & $\mathrm{L}$ & 48 & Menikah & HPV 18 \\
\hline 27 & L27 & $\mathrm{L}$ & 62 & Menikah & HPV 18 \\
\hline 28 & L28 & $\mathrm{P}$ & 44 & Menikah & HPV 18 \\
\hline 29 & L29 & $\mathrm{L}$ & 75 & Menikah & HPV 18 \\
\hline 30 & $\mathrm{~L} 30$ & $\mathrm{P}$ & 45 & Menikah & HPV 18 \\
\hline 31 & L31 & $\mathrm{L}$ & 26 & Belum & HPV 18 \\
\hline 32 & L32 & $\mathrm{P}$ & 44 & Menikah & HPV 18 \\
\hline 33 & L33 & $\mathrm{L}$ & 28 & Belum & HPV 18 \\
\hline $\sec$ & Uant & & & $\begin{array}{l}\text { kerja (Bab } \\
\text { diisolasi ken } \\
\text { kuantitatif mau } \\
\text { secara kualit }\end{array}$ & $\begin{array}{lrr}\text { V).DNA yang } & \text { berhasil } \\
\text { udian diukur } & \text { secara } \\
\text { pun kualitatif.Pengukuran } \\
\text { tif dilakukan dengan }\end{array}$ \\
\hline
\end{tabular}


visualisasi pita-pita DNA pada gel agarosa $1 \%$.Hasil isolasi DNA secara kualitatif dapat dilihat pada Gambar 1.

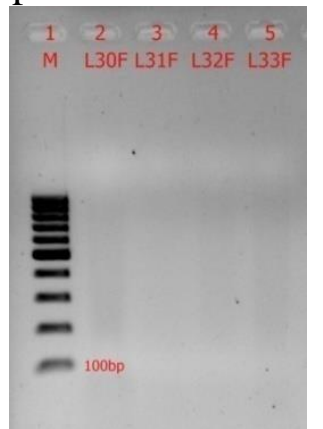

\section{Gambar 1. Hasil Visualisasi DNA DNA FFPE}

Hasil visualisasi DNA dari sampel FFPE menunjukkan bahwa DNA sampel mengalami fragmentasi sehingga DNA tidak tampak sebagai pita tunggal. Kemurnian DNA sangat penting dalam amplifikasi DNA dengan metode PCR, namun dalam penelitian ini meskipun kemurnian DNA rendah akan tetapi dapat digunakan untuk deteksi dan genotyping HPV 16/18.

\section{B. Genotyping Human Papillomavirus (HPV) 16/18}

Genotyping HPV 16/18 dilakukan pada DNA yang berasal darisampel jaringan FFPE dengan amplifikasi DNA menggunakan metode nested. PCR menggunakan consencus primer HPV Open Reading Frame (ORF) yang spesifik untuk daerah L1, E6 dan E7 kemudian produk PCR dari consencus primer diamplifikasi kembali dengan menggunakan sepasang primer HPV 16 untuk typing HPV 16 dan primer HPV 18 untuk typing HPV 18. Hasil genotyping HPV 16/18 ditunjukkan pada Tabel 2.

Tabel 2. Perbedaan hasil amplifikasi sekuen L1 HPV 16 dan HPV 18

\begin{tabular}{|c|c|c|c|c|c|c|c|c|c|c|c|c|c|c|c|c|c|c|c|c|c|c|}
\hline Primer & \multicolumn{22}{|c|}{ Sekuen } \\
\hline HPV F & 5 , & G & $\mathrm{C}$ & M & C & A & G & G & G & W & $\mathrm{C}$ & A & $\mathrm{T}$ & A & A & Y & A & A & $\mathrm{T}$ & G & G & 3 ' \\
\hline HPV 16 & 5 ' & - & - & A & - & - & - & - & - & $\mathrm{C}$ & - & - & $\mathrm{C}$ & - & - & $\mathrm{C}$ & - & - & - & - & - & 3 ' \\
\hline HPV 18 & 5 , & - & - & A & - & - & - & - & - & $\mathrm{T}$ & - & - & $\mathrm{C}$ & - & - & - & - & - & - & - & - & $3^{\prime}$ \\
\hline HPV R & $5^{\prime}$ & $\mathrm{C}$ & G & $\mathrm{T}$ & $\mathrm{C}$ & $\mathrm{C}$ & M & A & $\mathrm{R}$ & $\mathrm{R}$ & G & G & A & W & A & $\mathrm{C}$ & $\mathrm{T}$ & G & A & $\mathrm{T}$ & $\mathrm{C}$ & $3{ }^{\prime}$ \\
\hline HPV 16 & 5 , & - & _ & - & - & _ & $\mathrm{T}$ & _ & A & A & _ & _ & _ & A & _ & - & _ & - & _ & _ & _ & $3^{\prime}$ \\
\hline HPV 18 & 5 ' & & & & $=$ & $=$ & A & - & G & $\mathrm{G}$ & & $=$ & - & $\mathrm{T}$ & $=$ & $\mathrm{T}$ & - & $=$ & - & - & - & $3^{\prime}$ \\
\hline
\end{tabular}


Hasil elektroforesis genotyping HPV 16 dan HPV 18 pada sampel FFPE masing-masing dapat diamati pada gambar 2 dan 3.

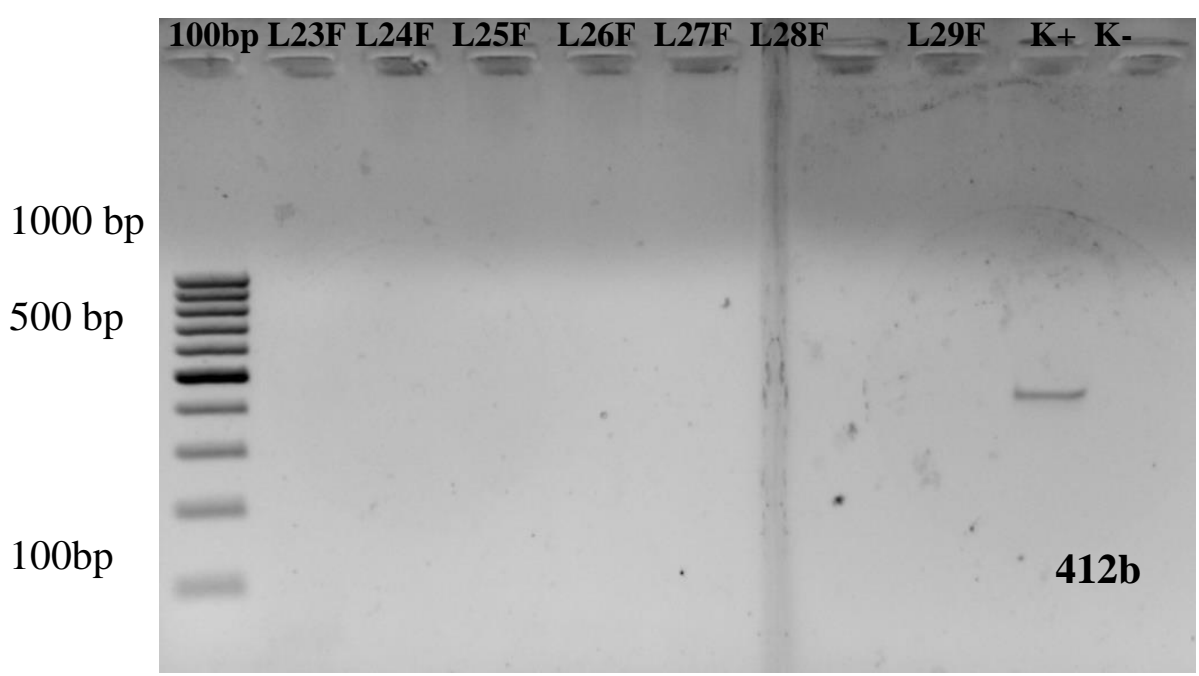

Gambar 2.Contoh hasil genotyping HPV 16 pada sampel FFPE Karsinoma Sel Skuamosa Kepala dan Leher. Hasil positif sampel terinfeksi HPV 16 ditandai dengan munculnya pitaberukuran 412 bp seperti ditunjukkan pada kontrol positif $(\mathrm{K}+)$. Berdasar hasil genotyping pada seluruhsampel FFPE tidak didapat hasil positif untuk genotyping HPV 16. K+ adalah kontrol positif HPV 16 (sampel jaringan segar kanker serviks) dan K- adalah kontrol negatif HPV 16 (Non Template Control/ NTC). Genotyping HPV 16 pada 33 sampel FFPE karsinoma sel skuamosa kepala dan leher menunjukkan hasil yang negatif, ditandai dengan tidak munculnya pita tunggal pada 412 bp seperti yang ditunjukkan pada kontrol positif $(\mathrm{K}+)$.

Genotyping HPV 18 pada sampel FFPE kanker kepala dan leher menunjukkan hasil sebanyak 11 sampel positif HPV 18 atau $33 \%$ (11/33), yang ditandai dengan adanya pita tunggalberukuran 415 bp seperti yang ditunjukkan pada kontrol positifnya.

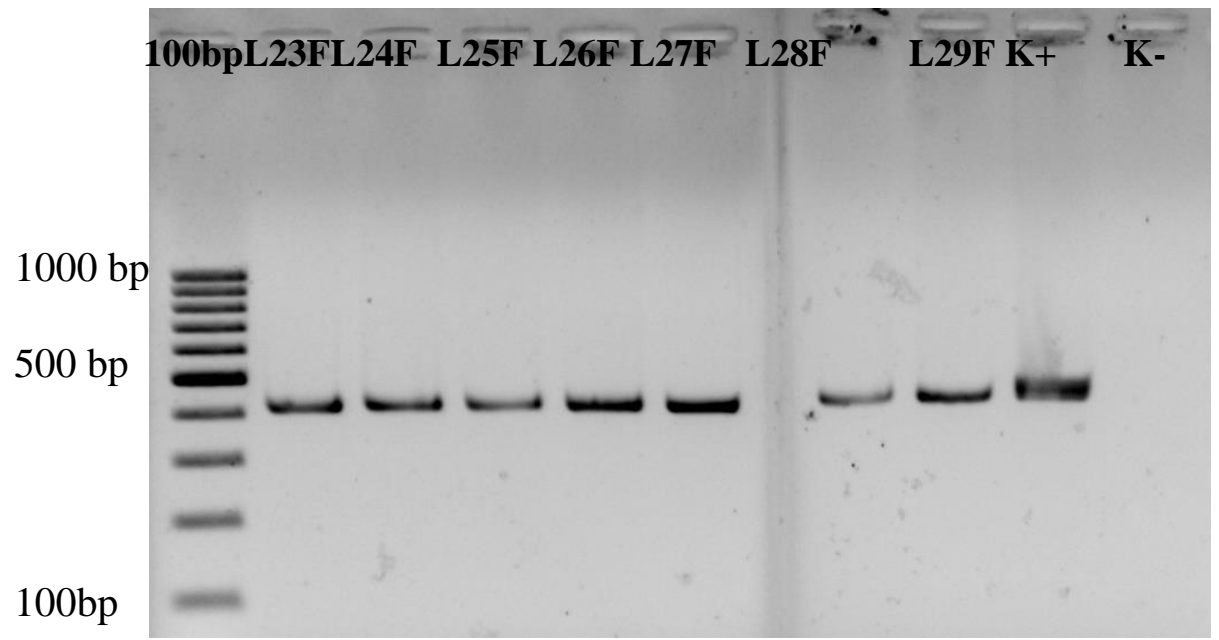

Gambar 3.Contoh hasil genotyping HPV 18 pada sampel FFPE Karsinoma Sel Skuamosa Kepala dan Leher. Hasil positif sampel terinfeksi HPV 18 ditandai dengan munculnya pitaberukuran 415 bp seperti ditunjukkan pada kontrol positif $(\mathrm{K}+) . \mathrm{K}+$ adalah kontrol positif HPV 18 (sampel jaringan segar kanker serviks) dan K- adalah kontrol negatif HPV18 (Non Template Control/NTC) 
Hubungan antara HPV dengan kanker esophangeal pertama kali ditemukan oleh Syrjanen pada tahun 1982, yang mengamati bahwa $40 \%$ dari 60 pasien dengan esophagus karsinoma sel skuamosa positifterinfeksi HPV. Pada penelitian ini, genotyping HPV 16/18 baik pada sampel FFPE, jaringan segar maupun darah perifer, tidak ditemukan adanya infeksi HPV 16 dan hanya 6 sampel terinfeksi HPV 18.

Infeksi HPV pada jaringan kanker kepala dan leher dapat mengindikasikan keterlibatan HPV pada perubahan epitelium rongga mulut.HPV memiliki dua onkoprotein yaitu E6 dan E7. E7 berikatan dengan $\mathrm{pRb}$, yang mengakibatkan E2F teraktifasi untuk menginisiasi siklus sel (fase G1 berlanjut ke fase $\mathrm{S}$ ). Adapun E6 berfungsi untuk menghancurkan (proteolisis) TP53, sehingga apoptosis tidak terinisiasi. Selain itu, E6 dari HPV menginaktivasi protein TP53 pada region Arg72 sehingga mencegah proses perbaikan DNA.Arg72 p53 rentan untuk mengalami proteolisis akibat kerja E6 HPV18 (Whitford, 2005). Kerja onkoprotein E6 dan E7 tersebut berakibat sel yang terinfeksi HPV terus menerus membelah, dan memfasilitasi perkembangan tumor(Leemans et al., 2011)

Berdasarkan sampel yang terinfeksi HPV 18 sebanyak 33\% (11 dari 33) sampel yang positif teridentifikasi HPV 18, diketahui $63 \%$ berasal dari pasien laki-laki dan sisanya perempuan. Penelitian lain juga menemukan $\quad 10,1 \% \quad(6 / 59) \quad$ laki-laki terinfeksi HPV 16 dan tidak ditemukan HPV 16 pada 11 pasien perempuan dengan kasus ESCC di Hongkong (Lam et al., 1997). Sebanyak $81 \%$ sampel kanker esopharingeal (26/32) yang terinfeksi HPV 18 adalah lakilaki, sedangkan $19 \% \quad(6 / 32)$ adalah perempuan, pasien berasal dari Amerika serikat bagian selatan (Wang, Gerstein, \& Snyder, 2009). Beberapa studi mengindikasikan bahwa infeksi HPV pada rongga mulut dan faring merupakan akibat perilaku seksual. Terdapat asosiasi yang kuat antara perilaku seksual dengan resiko kanker kepala dan leher akibat infeksi HPV(G D'Souza et al., 2007). Oral sex activity dan open-mouthed kissing menjadi penyebab terjadinya infeksi HPV yang menyebabkan KSS Rongga mulut (Gypsyamber D'Souza, Agrawal, Halpern, Bodison, \& Gillison, 2009)

Pada perempuan, selain karena perilaku seksual, terjadinya metastasis HPV dari kanker serviks dapat menjadi penyebab infeksi HPV pada rongga mulut dan faring. Ada kemiripan antara infeksi HPV positif pada kanker kepala dan leher dengan HPV positif pada kanker serviks (Lajer \& von Buchwald, 2010). Selain karena perilaku seksual dan metastasis jauh viral HPV dari serviks menuju ke rongga mulut dan faring, transfusi darah juga dapat menjadi faktor penyebab infeksi HPV 16/18 pada rongga mulut dan faring yang menyebabkan kanker. Sebanyak 8,3\% (15/180) donor darah sehat laki-laki (Australian RBC) terinfeksi (Chen et al., 2011) dan diketahui bahwa 3 dari 19 sampel yang diisolasi dari PBMCs darah donor (United States) positif terinfeksi HPV 16 (Bodaghi et al., 2005). Dalam penelitian ini, tidak dapat dipastikan penyebab infeksi HPV karena tidak ada data pendukung mengenai riwayat kanker serviks, perilaku seksualnya maupun riwayat transfusi darah. Selain itu, kami juga tidak ditemukan adanya infeksi HPV pada sampel darah perifer sehingga tidak dapat dijelaskan metode transmisi HPV pada sampel yang digunakandalam penelitian ini.

\section{SIMPULAN}


Pemeriksaan HPV 16/18 dengan metode nested PCR menunjukkkan hasil positif HPV genotipe 18 sebanyak 33,33\% (11/33) FFPE, menunjukkan hasil negatif untuk pengujian HPV genotype 16. Hasil menunjukkan bahwa metode nested PCR dapat digunakan untuk memeriksa infeksi HPV 18 pada isolat DNA dari sampel FFPE.

\section{DAFTAR PUSTAKA}

Blot, W. J., McLaughlin, J. K., Winn, D. M., Austin, D. F., Greenberg, R. S., Preston-Martin, S., ... Fraumeni, J. F. (1988). Smoking and drinking in relation to oral and pharyngeal cancer. Cancer Research, 48(11), 3282-3287.

Bodaghi, S., Wood, L. V., Roby, G., Ryder, C., Steinberg, S. M., \&Zheng, Z. M. (2005). Could human papillomaviruses be spread through blood? Journal of Clinical Microbiology, 43(11), 5428-5434.

Carter, J. J., Madeleine, M. M., Shera, K., Schwartz, S. M., Cushing-Haugen, K. L., Wipf, G. C., ... Galloway, D. A. (2001). Human papillomavirus 16 and $18 \mathrm{~L} 1$ serology compared across anogenital cancer sites. Cancer Research, 61(5), 1934-1940.

Chen, A. C.-H., Waterboer, T., Keleher, A., Morrison, B., Jindal, S., McMillan, D., ... Antonsson, A. (2011). Human papillomavirus in benign prostatic hyperplasia and prostatic adenocarcinoma patients. Pathology Oncology Research: POR, 17(3), 613-7.

Chin, D., Boyle, G. M., Theile, D. R., Parsons, P. G., \& Coman, W. B. (2004). Molecular introduction to head and neck cancer (HNSCC) carcinogenesis. British Journal of Plastic Surgery, 57(7), 595-602.

D’Souza, G., Agrawal, Y., Halpern, J., Bodison, S., \& Gillison, M. L. (2009). Oral sexual behaviors associated with prevalent oral human papillomavirus infection. The Journal of Infectious Diseases, 199(9), 1263-1269.

D’Souza, G., Kreimer, A. R., Viscidi, R., Pawlita, M., Fakhry, C., Koch, W. M., ... Gillison, M. L. (2007). Casecontrol study of human papillomavirus and oropharyngeal cancer. The New England Journal of Medicine, 356(19), 1944-1956.

Gasco, M., \& Crook, T. (2003). The p53 network in head and neck cancer. Oral Oncology. http://doi.org/10.1016/S13688375(02)00163-X

Kabat, G. C., Chang, C. J., \& Wynder, E. L. (1994). The role of tobacco, alcohol use, and body mass index in oral and pharyngeal cancer. International Journal of Epidemiology, 23(6), 1137-1144.

Lajer, C. B., \& von Buchwald, C. (2010). The role of human papillomavirus in head and neck cancer. APMIS : Acta Pathologica, Microbiologica, et Immunologica Scandinavica, 118(67), 510-519.

Lam, K. Y., He, D., Ma, L., Zhang, D., Ngan, H. Y., Wan, T. S., \& Tsao, S. W. (1997). Presence of human papillomavirus in esophageal squamous cell carcinomas of Hong Kong Chinese and its relationship with p53 gene mutation. Hum Pathol, 28(6), 657-663. R

Leemans, C. R., Braakhuis, B. J. M., \& Brakenhoff, R. H. (2011). The 
JURNAL IPTEKS TERAPAN

Research of Applied Science and Education V10.i1 (25-33)
ISSN: 1979-9292

E-ISSN: 2460-5611

molecular biology of head and neck cancer. Nature Reviews. Cancer, 11(1), 9-22.

Manos, M. M., Waldman, J., Zhang, T. Y., Greer, C. E., Eichinger, G., Schiffman, M. H., \& Wheeler, C. M. (1994). Epidemiology and partial nucleotide sequence of four novel genital human papillomaviruses. The Journal of Infectious Diseases, 170(5), 1096-1099.

Marur, S., D’Souza, G., Westra, W. H., \& Forastiere, A. A. (2010). HPVassociated head and neck cancer: A virus-related cancer epidemic. The Lancet Oncology. http://doi.org/10.1016/S14702045(10)70017-6

McKaig, R. G., Baric, R. S., \& Olshan, A. F. (1998). Human papillomavirus and head and neck cancer: epidemiology and molecular biology. Head \& Neck, 20(3), 250-265.

Sankaranarayanan, R., Nair, M. K., Mathew, B., Balaram, P., Sebastian, P., \& Dutt, S. C. (1992). Recent results of oral cancer research in Kerala, India. Head and Neck, 14(2), 107-112.

Shen, H., Zheng, Y., Sturgis, E. M., Spitz, M. R., \& Wei, Q. (2002). P53 codon 72 polymorphism and risk of squamous cell carcinoma of the head and neck: A case-control study. Cancer Letters, 183(2), 123-130.

Wang, Z., Gerstein, M., \& Snyder, M. (2009). RNA-Seq: a revolutionary tool for transcriptomics. Nature Reviews. Genetics, 10(1), 57-63. 